\title{
Pengelolaan Zakat, Infaq dan Sedekah dalam Upaya Meningkatkan Pendapatan Ekonomi Pelaku UMKM di BAZNAS Kota Pasuruan
}

\author{
Nur Aini, Abdillah Mundir \\ Universitas Yudharta Pasuruan \\ aini07121@gmail.com, abdillahmundir@yudharta.ac.id
}

\section{Article Info}

Article history:

Received Oct19th, 2020

Revised Oct 30th, 2020

Accepted Nov 5th, 2020
Keyword:

Management,

Zakat,

Infaq and Sedekah,

UMKM

\begin{abstract}
This study aims to look at the management system of zakat, infaq and alms in an effort to improve the economy of small and medium enterprises in BAZNAS Pasuruan City, to see changes in the economy of mustahik after receiving ZIS assistance from BAZNAS Pasuruan City. The method used in this research is a qualitative method using this type of field research (field research). The study used observation data learning techniques, interviews, and documentation. The results of this study indicate that the zakat, infaq and alms funds collected from BAZNAS Pasuruan City come from residents of Pasuruan City and Pasuruan City Offices. ZIS funds are distributed to small and medium business actors so that they can develop their business and with the assistance of ZIS funds for micro and medium entrepreneurs, this has resulted in changes in the mustahik economy for the better.
\end{abstract}

Copyright@2020 Program Studi Ekonomi Syariah Universitas Yudharta Pasuruan All rights reserved.

DOI: https://doi.org/10.35891/ml.v12i1.2367

\section{Corresponding Author:}

Abdillah Mundir,

Lecturer in Sharia Economics, University of Yudharta Pasuruan

Email: abdillahmundir@yudharta.ac.id 


\section{A. Pendahuluan}

Kemiskinan merupakan salah satu permasalahan besar yang ada di Indonesia, bahkan di tahun 1997 Indonesia pernah mengalami krisis moneter yang hal itu mengakibatkan angka kemiskinan di Indonesia meningkat. Hal ini merupakan salah satu dampak dari sekian banyaknya usaha kegiatan ekonomi yang terhenti sehingga mengakibatkan angka pengangguran meningkat. Dalam bidang ekonomi, zakat mencegah terjadinya penumpukan kekayaan pada segelintir orang saja dan mewajibkan orang kaya untuk mendistribusikan harta kekayaan kepada orang miskin. Zakat merupakan sumber potensial untuk mengentaskan kemiskinan. Zakat dapat berfungsi sebagai modal kerja bagi orang miskin agar dapat membuka lapangan pekerjaan. Dia bisa berpenghasilan dan dapat memenuhi kebutuhan hidupnya. Tujuan aturan zakat adalah menciptakan distribusi pendapatan menjadi lebih merata. Selain untuk tujuan distribusi, analisis kebijakan fiskal dan sistem ekonomi dilakukan untuk stabilitas kegiatan ekonomi. Allah memerintahkan umatnya untuk menunaikan zakat, infaq dan sedekah. Zakat disebut juga sedekah wajib atau infak wajib (Suryadi \& Putri, 2018). Dalam pengertian bahwa pengaturan zakat telah ditentukan jenis, jumlah yang wajib dizakati, serta waktu pelaksanaan zakat tersebut. Selain zakat, ada beberapa istilah lain, yaitu infak dan sedekah (shadaqah). Yang dimaksud dengan infak adalah harta yang dikeluarkan oleh seseorang atau badan usaha di luar zakat untuk kemaslahatan umum, sedangkan yang dimaksud sedekah adalah harta atau non harta yang dikeluarkan oleh seseorang atau badan usaha diluar zakat untuk kemaslahatan umum. Dalam kenyataannya, tidak sedikit orang Islam tidak mau menunaikan keharusannya itu. Di antara mereka ada yang khawatir bila ZIS itu ditunaikan hartanya akan berkurang, bahkan bisa jadi ia menjadi miskin. Allah Swt juga menjanjikan bertambahnya manfaat harta bagi orang yang membelanjakan hartanya di jalan yang benar (Juwarta, 2015). Allah Swt berfirman:

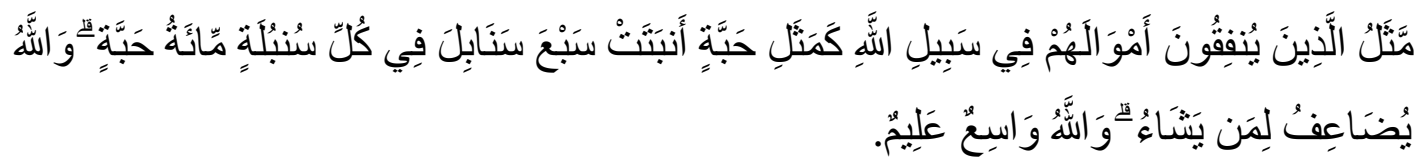

Perumpamaan (nafkah yang dikeluarkan oleh) orang-orang yan menafkahkan hartanya di jalan Allah adalah serupa dengan sebutir benih yang menumbuhkan tujuh bulir, pada tiap-tiap bulir seratus biji. Allah melipat gandakan (ganjaran) bagi siapa yang dia kehendaki. Dan Allah maha Luas (karunianya) lagi maha mengetahui. (QS. Al-Baqarah: 261).

Badan Amil Zakat Nasional (BAZNAS) merupakan badan resmi dan satu-satunya yang dibentuk oleh pemerintah yang memiliki tugas dan fungsi menghimpun dan menyalurkan zakat, infaq dan sedekah (ZIS) pada tingkat nasional. Lahirnya UndangUndang Nomor 23 tahun 2011 tentang Pengelolaan Zakat semakin mengukuhkan peran BAZNAS sebagai lembaga yang berwenang melakukan pengelolaan zakat secara nasional. Dalam UU tersebut, BAZNAS dinyatakan sebagai lembaga pemerintah nonstructural yang bersifat mandiri dan tanggung jawab kepada Presiden melalui Menteri Agama (Purnamasari \& Firdaus, 2017). Dengan demikian, BAZNAS bersama Pemerintah 
bertanggung jawab untuk mengawal pengelolaan zakat yang berasaskan: Syariat Islam, amanah, kemanfaatan, keadilan, kepastian hukum, terintegrasi dan akuntabilitas. BAZNAS Kota Pasuruan merancang sebuah progam kerja yang salah satunya adalah program Kota Pasuruan Makmur yang bertujuan untuk mensejahterakan kehidupan para penerimanya sehingga mampu menjalankan usaha secara mandiri dan meningkatkan kesejahteraan (Ilyas, 2018).

Program Kota Pasuruan Makmur disalurkan dalam bentuk pinjaman modal usaha, pelatihan usaha, konsultasi usaha, evaluasi usaha serta melibatkan mitra pihak ketiga. Tujuan utama dari program ini adalah meningkatkan daya guna ZIS sehingga dana yang disalurkan tidak hanya habis untuk kebutuhan sehari-hari tetapi juga mampu diputar kembali agar mampu memperoleh penghasilan dari zakat, infaq, dan sedekah (Khasanah \& Suryaningsih, 2019). Adapun penyaluran zakat, infaq dan sedekah di Baznas Kota Pasuruan dengan memberikan bantuan usaha kepada warga yang termasuk ke dalam 8 (delapan) golongan yang berhak menerima bantuan dana zakat produktif sebagai salah satu pembinaan dan menjadi penyambung hidup bagi masyarakat itu sendiri. Dengan adanya upaya-upaya tersebut, diharapkan akan dapat meningkatkan kemampuan usaha kecil dalam menghadapi persaingan yang sangat ketat dipasar bebas. Pada akhirnya, diharapkan agar perbankan mampu meningkatkan pemberian kredit usaha kecilnya baik secara kualitas maupun kuantitasnya. Akan tetapi, pada kenyataannya tidak sesuai karena sulitnya mengakses lembaga kredit formal yang disebabkan oleh beberapa hal seperti tingginya ketidakpastian kemampuan pelaku UMKM dalam pengembalian pinjaman modal tersebut, tidak mempunyai jaminan yang bisa dijaminkan, serta tidak memiliki izin usaha sebagai bukti legalitas usaha. Pengusaha UMKM yang terhimpit biasanya sering kali beralih ke rentenir. Dimana rentenir dapat memberikan dana secara cepat dengan persyaratan mudah dan jumlah pinjamannya cenderung besar. Namun pinjaman pada rentenir justru akan lebih memberatkan pada pengusaha UMKM karena tingginya beban bunga yang diberikan. Mencegah maraknya pinjaman pada rentenir yang tidak bertanggung jawab maka lembaga BAZNAS Kota Pasuruan dalam pengelolaan zakat, infaq dan sedekah mengembangkan program Kota Pasuruan Makmur. Pada program ini, dana zakat, infaq dan sedekah disalurkan sebagai pinjaman modal usaha, pelatihan, dan lain sebagainya. Fenomena ZIS di Kota Pasuruan yang kita lihat menggambarkan zakat, infak dan sedekah (ZIS) yang telah dijalankan oleh BAZNAS Kota Pasuruan, yang pada kenyataannya menjadi program yang dijalankan oleh BAZNAS, mereka melihat pentingnya mengembangkan ZIS untuk meningkatkan pertumbuhan pelaku UMKM dan kesejahteraan mustahik.

\section{B. Kajian Teori}

\section{Pengelolaan}

Pengelolaan merupakan terjemahan dari kata "management" di dalam kamus besar bahasa Indonesia bahwa pengelolaan berarti menyelenggarakan, Manajemen adalah proses perencanaan, pengorganisasian, pengoordinasian, dan pengontrolan sumber daya untuk mencapai sasaran (goals) secara efektif dan efisien. Manajemen 
adalah proses pengoordinasi kegiatan-kegiatan sehingga pekerjaan tersebut terselesaikan secara efisien dan efektif dengan dan melalui orang lain. Jadi bisa ditarik kesimpulan bahwa pengelolaan adalah suatu tindakan yang dimulai dari penyusunan data, perencanaan, mengorganisasikan, pengkoordinasian dan melaksanakan sampai dengan pengawasan dan penilaian (Sanihah, 2014; Syafi'i, 2019; Wahiddudin, 2019).

\section{Zakat}

Zakat secara bahasa berarti tumbuh, berkembang, subur, bertambah, menyucikan, dan membersihkan. Adapun zakat menurut istilah fikih berarti sejumlah harta tertentu yang diwajibkan Allah diserahkan kepada orang-orang yang berhak. Berdasarkan definisi tersebut bisa disimpulkan bahwa zakat itu kewajiban orang kaya terhadap hartanya untuk diserahkan kepada mustahik, yang standarnya telah ditentukan oleh syariat Islam(Nizar, 2015; Tatang Ruhiat, 2020). Zakat terdiri dari dua macam yaitu:

a. Zakat Mal, yaitu zakat yang diwajibkan atas harta berdasarkan syarat-syarat tertentu atau harta yang dimiliki oleh muzakki perseorangan atau badan usaha. Zakat mal meliputi: emas, perak, logam mulia, uang, surat berharga, perniagaan, pertanian, peternakan, perindustrian dan lain sebagainya.

b. Zakat Fitrah, yaitu zakat yang wajib dizakatkan pada bulan Ramadhan. Kadang zakat fitrah disebut dengan zakat badan atau sedekah fitrah.

Syarat wajib zakat ada 3 yaitu:

c. Islam artinya orang yang mengeluarkan zakat harus beragama Islam baik anakanak maupun dewasa.

d. Berakal dan baligh artinya anak kecil atau orang gila yang memiliki harta yang mencapai satu nisab maka tidak dapat dikenakan zakat, karena mereka tidak dituntut untuk melakukan ibadah. Akan tetapi anak kecil setelah baligh maka wajib mengeluarkan zakat. Begitu juga dengan orang gila akan wajib apabila sudah waras.

e. Merdeka artinya harta yang dimiliki oleh seorang muslim yang berakal sehat dan merdeka.

Orang-orang Yang Berhak Menerima Zakat ada 8 yaitu:

a. Orang fakir adalah orang yang tidak memiliki harta untuk menunjang kehidupan dasarnya.

b. Orang miskin adalah orang yang tidak memiliki harta untuk kehidupan dasarnya, namun ia mampu berusaha mencari nafkah, hanya penghasilannya tidak mencukupi bagi kehidupan dasarnya untuk kehidupannya sendiri atau keluarganya.

c. Amil yaitu orang yang ditunjuk oleh penguasa yang sah yang mengurus zakat, baik mengumpulkan, memelihara, membagi, dan mendayagunakan serta petugas lain yang ada hubungannya dengan pengurus zakat. 
d. Mualaf yaitu orang-orang yang baru masuk Islam dan memerlukan masa pemantapan dalam agama barunya itu dan untuk itu memerlukan dana.

e. Riqob, kata riqob berarti pembudakan yang dimaksud adalah untuk memerdekakan budak, baik dengan membeli budak-budak untuk kemudian dimemerdekakan, atau memberi dana untuk kepentingan menebus dirinya dari perbudakan.

f. Gharimin yaitu orang-orang yang dililit oleh utang dan tidak dapat melepaskan dirinya dari jeratan utang itu kecuali dengan bantuan dari luar.

g. Sabilillah yaitu orang-orang yang menegakkan syiar agama Islam.

h. Ibnu sabil yaitu orang-orang yang berada dalam perjalanan bukan untuk tujuan maksiat, yang kehabisan biaya dalam perjalanannya dan tidak mampu meneruskan perjalanannya kecuali dengan bantuan dari luar.

\section{Infaq}

Infaq berasal dari kata anfaqo yang berarti mengeluarkan suatu harta untuk kepentingan sesuatu. Sedangkan menurut terminology syariat, infaq berarti mengeluarkan sebagian dari harta atau pendapatan atau penghasilan untuk suatu kepentingan yang diperintahkan ajaran Islam (Anik \& Prastiwi, 2019; Muayyanah et al., 2019; Tatang Ruhiat, 2020).

\section{Sedekah}

Sedekah adalah harta atau non harta yang dikeluarkan oleh seseorang atau badan usaha di luar zakat untuk kemaslahatan umum. Dalam istilah syari'at Islam, sedekah sama dengan pengertian infaq, termasuk juga hukum dan ketentuanketentuannya. Sisi perbedaan hanya terletak pada bendanya. Artinya, Infaq berkaitan dengan materi dan non materi, baik dalam bentuk pemberian benda atau uang, tenaga atau jasa, menahan diri untuk tidak berbuat kejahatan, mengucapkan takbir, tahmid, tahlil, bahkan yang paling sederhana adalah tersenyum kepada orang lain secara ikhlas (Sisweda et al., 2020).

\section{Lembaga Pengelolaan Zakat, Infaq dan Sedekah}

Di Indonesia, pengelolaan zakat diatur dalam Undang-Undang RI Nomor 23 tahun 2011 tentang Pengelolaan Zakat. Dimana dalam undang-undang tersebut terdapat beberapa bab yang menjelaskan tentang lembaga pengelola zakat yang ada di Indonesia yang terdiri dari dua lembaga yaitu: BAZNAS (Badan Amil Zakat Nasional) dan LAZ (Lembaga Amil Zakat). Meskipun dalam peraturan-peraturan tersebut masih banyak kekurangan tetapi undang-undang tersebut mendorong upaya pembentukan lembaga pengelola zakat yang amanah, kuat dan dipercaya oleh masyarakat (Lukito, 2014; Yudhira, 2020).

\section{Pendapatan}

Pendapatan merupakan salah satu unsur yang paling utama dari pembentukan laporan laba rugi dalam suatu perusahaan. Banyak yang bingung mengenai istilah 
pendapatan. Hal ini disebabkan pendapatan dapat ditarik sebagai revenue dan dapat juga diartikan juga sebagai income,maka income dapat diartikan sebagai penghasilan dan kata revenue sebagai pendapatan penghasilan maupun keuntungan. Pendapatan adalah pendapatan uang yang diterima dan diberikan kepada subjek ekonomi berdasarkan prestasi-prestasi yang diserahkan yaitu berupa pendapatan dari profesi yang dilakukan sendiri atau usaha perorangan dan pendapatan dari kekayaan. Besarnya pendapatan seseorang bergantung pada jenis pekerjaannya (Rakhmawati et al., 2019; Wicaksono, 2018). Jenis-jenis pendapatan yang dilaporkan dalam laporan laba rugi terdiri dari dua jenis yaitu:

a. Pendapatan atau penghasilan yang diperoleh dari usaha pokok (usaha utama) perusahaan.

b. Pendapatan atau penghasilan yang diperoleh dari luar usaha pokok (usaha sampingan) perusahaan.

\section{Usaha Mikro Kecil Menengah}

UMKM adalah unit usaha produktif berdiri yang sendiri, yang dilakukan oleh orang atau perorangan atau badan usaha di semua sector ekonomi. Pada prinsipnya, pembedaan antara Usaha Mikro (UMI), Usaha Kecil (UK), Usaha Menengah (UM), dan Usaha Besar (UB) umumnya didasarkan pada nilai asset awal (tidak termasuk tanah dan bangunan), omset rata-rata per tahun, atau jumlah pekerja tetap. Namun definisi UMKM berdasarkan tiga alat ukur ini berbeda menurut Negara. Karena itu memang sulit membandingkan pentingnya atau peran UMKM antar Negara (Antin Rakhmawati et al., 2019; Nizar, 2016).

\section{Metode}

Jenis penelitian yang dilakukan dalam penelitian ini adalah penelitian kualitatif. Adapun yang dimaksud kualitatif adalah penelitian yang bermaksud untuk memahami fenomena tentang apa yang dialami oleh subjek penelitian misalnya perilaku, persepsi, motivasi, tindakan, dll. Secara holistik, dan dengan cara deskripsi dalam bentuk kata-kata dan bahasa, pada suatu konteks khusus yang alamiah dan dengan memanfatkan berbagai metode alamiah. Sedangkan pendekatan penelitian yang digunakan adalah studi kasus. Adapun yang dimaksud studi kasus adalah suatu penelitian yang menyelidiki fenomena dalam konteks kehidupan nyata bilamana batas-batas antara fenomena dan konteks tidak tampak dengan tegas, dimana berbagai sumber bukti dimanfaatkan (Hendriyani et al., 2017).

Dalam melakukan penelitian dan untuk memperoleh data sebanyak mungkin peneliti menggunakan cara studi lapangan. Dalam hal ini peneliti menggunakan pendekatan kualitatif. Oleh karena itu kehadiran peneliti menjadi hal yang sangat penting. Didalam penelitian ini, peneliti bertindak sebagai pengumpul data dan sebagai instrumen aktif dalam upaya mengumpulkan data-data dilapangan. Sedangkan instrument pengumpulan data yang lain selain manusia adalah berbagai bentuk alat-alat bantu dan berupa dokumen-dokumen lainnya yang dapat digunakan untuk menunjang keabsahan

100 | Pengelolaan Zakat, Infaq dan Sedekah dalam Upaya Meningkatkan Pendapatan... 
penelitian, namun berfungsi sebagai instrument pendukung. Oleh karena itu, kehadiran peneliti secara langsung dilapangan sebagai tolak ukur keberhasilan untuk memahami kasus yang diteliti, sehingga keterlibatan peneliti secara langsung dan aktif dengan informan dan sumber lainnya di sini sangat mutlak diperlukan (Indriantoro \& Supomo, 2016).

Lokasi penelitian yang dipilih dalam penelitian ini adalah di Kantor Badan Amil Zakat Nasional (BAZNAS) Kota Pasuruan yang bertempat di Jl. Panglima Sudirman, Kebonagung, Kecamatan Purworejo, Kota Pasuruan, Jawa Timur 67111, (0343) 5643993. Dalam penelitian ini penulis menggunakan dua jenis data yaitu data primer dan data sekunder. Sumber data primer adalah sumber data yang langsung memberikan data kepada pengumpul data. Dalam penelitian ini data primer diperoleh dari lembaga yang ditelitinya. Oleh karena itu untuk mengetahui kebenaran data dari hasil wawancara, dokumentasi dan data lapangan kepada narasumber yaitu Pimpinan Baznas, staff Baznas Kota Pasuruan dan pelaku UMKM. Sumber data sekunder adalah Sumber yang tidak langsung memberikan data kepada pengumpul data, misalnya lewat orang lain atau lewat dokumen. Bisa dari sumber-sumber yang tertulis (majalah ilmiah, buku, arsip dan dokumen pribadi) (Sekaran \& Bougie, 2017).

Dalam melakukan penelitian ini ada beberapa teknik pengumpulan data yaitu Observasi atau pengamatan adalah penginderaan secara langsung terhadap suatu benda, kondisi, situasi, proses atau perilaku. Dalam penelitian menggunakan pengamatan langsung atau observasi sebagai metode pengumpulan data. Nasution mengartikan observasi sebagai "dasar semua ilmu pengetahuan". Wawancara adalah percakapan yang dilakukan oleh dua pihak, yaitu pewawancara (interviewer) yang mengajukan pertanyaandan terwawancara (interviewee) yang memberikan jawaban atas pertanyaan itu. Dokumentasi adalah mencari data dengan menggali dan menganalisis data yang berbentuk surat-surat, catatan harian, buku-buku, karya ilmiah, dokumen-dokumen dan sebagainya. Dari data yang berhasil dikumpulkan akan disusun, dianalisa dan kemudian disajikan secara tertulis dalam bentuk laporan penelitian. Untuk mengolah data yang terkumpul dilakukan dengan menggunakan teknik analisa data kualitatif deskriptif, yaitu analisa yang digunakan untuk menganalisis data dengan cara mendeskripsikan atau menggambarkan data yang telah terkumpul sebagaimana adanya tanpa bermaksud membuat kesimpulan yang berlaku untuk umum atau generalisasi (Sekaran \& Bougie, 2017).

Dalam penelitian, setiap hal temuan harus di cek keabsahannya agar hasil penelitiannya dapat dipertanggungjawabkan kebenarannya dan dapat di buktikan keabsahannya. Untuk pengecekan keabsahan temuan ini teknik yang dipakai adalah triangulasi. Triangulasi adalah pemeriksaan keabsahan data yang memanfaatkan sesuatu yang lain (Purhantara, 2010). 


\section{Hasil dan Pembahasan}

\section{Prosedur Pengelolaan Dana Zakat, Infaq dan Sedekah dalam Meningkatkan Pendapatan Ekonomi Pelaku UMKM}

Baznas Kota Pasuruan adalah Badan Amil Zakat Nasional (BAZNAS) merupakan badan resmi yang dibentuk oleh pemerintah berdasarkan Keputusan Presiden RI No. 8 Tahun 2001 yang memiliki tugas dan fungsi menghimpun dan menyalurkan zakat, infaq, dan sedekah (ZIS) pada tingkat nasional sampai daerah. Lahirnya Undang-Undang Nomor 23 Tahun 2011 tentang Pengelolaan Zakat semakin mengukuhkan peran Baznas Kota Pasuruan sebagai lembaga yang berwenang melakukan pengelolaan zakat secara profesional yang bertanggung jawab kepada masyarakat khususnya walikota Pasuruan dan Baznas Jatim. Dengan demikian, Baznas bersama Pemerintah bertanggung jawab untuk mengawal pengelolaan zakat yang berasskan: syariat Islam, amanah, kemanfaatan, keadilan, kepastian hukum, terintegrasi dan akuntabel.

Pengelolaan zakat bukanlah semata-mata dilakukan secara individual dari muzakki kepada mustahik, akan tetapi dilakukan oleh sebuah lembaga yang khusus menangani zakat, yang memenuhi persyaratan tertentu yang disebut "Amil Zakat". Kata amil yang berarti pengurus zakat dan kata khuz yang berarti ambillah, maka perintah untuk memungut zakat melalui lembaga yang mengurus zakat, ini menuntut perlunya sebuah Badan Amil Zakat sesuai dengan amanah Undang-Undang Nomor 23 Tahun 2011 tentang pengelolaan zakat.

Pengelolaan zakat yang dilakukan oleh lembaga pengelola zakat, yang memiliki kekuatan hukum formal, akan memiliki beberapa keuntungan yaitu: Pertama, untuk menjamin kepastian dan disiplin pembayar zakat. Kedua, untuk menjaga perasaan rendah diri para mustahik apabila bertemu langsung untuk menerima zakat dari para muzakki. Ketiga, untuk mencapai efisien dan efektivitas, serta sasaran yang tepat dalam penggunaan harta zakat menurut skala prioritas yang ada pada suatu tempat. Keempat, untuk memperlihatkan syiar Islam dalam semangat penyelenggaraan pemerintah yang Islami. Sebaliknya, jika zakat diserahkan langsung dari muzakki kepada mustahik, secara hukum syariah adalah sah, akan tetapi disamping akan terabaikannya hal-hal yang diatas, juga hikmah dan fungsi zakat, terutama yang berkaitan dengan kesejahteraan umat, akan sulit diwujudkan.

Dalam penyaluran dan penerapan dana modal usaha yang harus dilakukan Baznas Kota Pasuruan dengan cara membantu para pelaku usaha kecil dalam masalah permodalan. Dalam rangka mengembangkan usaha kecil secara terpadu, efektif dan efisien maka diperlukan suatu koordinasi dari berbagai instansi terkait dengan Baznas sesuai dengan tanggung jawab dan tugas masing-masing. Dengan cara tersebut diharapkan para pelaku usaha mikro bisa meningkatkan kemampuan dalam menghadapi persaingan pasar bebas dan persaingan pasar modern.

Baznas menjalankan empat fungsi yaitu: pertama adalah perencanaan, pengumpulan, pendistribusian dan pendayagunaan zakat, infaq dan sedekah (ZIS), kedua pelaksanaan, pengumpulan, pendistribusian dan pendayagunaan zakat, infaq 
dan sedekah (ZIS), ketiga pengendalian, pengumpulan, pendistribusian dan pendayagunaan zakat, infaq dan sedekah (ZIS), keempat pelaporan dan pertanggung jawaban pelaksanaan pengelolaan zakat, infaq dan sedekah.

Penyaluran dana ZIS yang dilakukan oleh Baznas Kota Pasuruan awalnya hanya untuk menyalurkan dana ZIS konsumtif saja yang bertujuan untuk memenuhi kebutuhan hidup sehari-hari para mustahik, dan pada tahun 2015 Baznas mulai mengalokasikan dana ZIS produktif untuk membantu usaha para mustahik supaya dapat mengembangkan usahanya. Dengan adanya dana ZIS maka mustahik bisa mengembangkan usahanya dan bisa membantu menambah permodalan usahanya. Dengan bantuan dana ZIS produktif diharapkan mampu membantu para pelaku usaha mikro untuk jangka panjang, karena apabila bantuan dana ZIS konsumtif diberikan maka hanya akan membantu pada jangka pendek saja. Penyaluran dana ZIS oleh Baznas Kota Pasuruan dapat menyumbangkan dan memberdayakan uang zakat secara produktif yang bertujuan untuk mengelola potensi zakat secara professional sehingga dana ZIS dapat meningkatkan perekonomian masyarakat terutama pengembangan usaha-usaha mikro kecil menengah.

Maka dari itu dalam penyaluran dana ZIS BAZNAS Kota Pasuruan benarbenar hati-hati dalam memberikan dana bantuan modal usaha tersebut. Apakah mustahik tersebut termasuk dari keluarga yang kurang mampu atau dari keluarga yang benar-benar membutuhkan bantuan. Sehingga BAZNAS Kota Pasuruan mempunyai syarat-syarat umum dalam pengajuan bantuan modal usaha seperti:

1. Termasuk kedalam 8 golongan ashnaf yang berhak menerima zakat.

2. Identitas diri.

3. Proposal permohonan yang diketahui masing-masing Unit Pengumpulan Zakat (UPZ) dilokasi setempat.

4. Akan menjalani verifikasi oleh BAZNAS sesuai dengan standart operasional yang berlaku.

\section{Upaya Meningkatkan Ekonomi Pelaku UMKM Melalui Dana ZIS}

BAZNAS Kota Pasuruan dalam penerapan Program Kota Pasuruan Makmur diberikan kepada setiap orang maupun usaha perkelompok dengan rata-rata setiap mustahik mendapatkan Rp. 1.000.000 bisa juga lebih tergantung dengan jenis usaha yang dijalaninya. Para mustahik diberikan bantuan dana sesuai dengan besaran usaha yang dijalankan. BAZNAS Kota Pasuruan menyiapkan program bantuan usaha baik program bantuan modal usaha bagi pemula, dan perbaikan tempat usaha.

Program Kota Pasuruan Makmur ini benar-benar sangat membantu para pelaku usaha mikro kecil menengah untuk mengembangkan usahanya menjadi lebih berkembang. Sehingga dapat membantu perubahan perekonomian pelaku usaha mikro kecil menengah yang awalnya terkategorikan kurang mampu tapi setelah usahanya berkembang dengan baik mampu meningkatkan ekonomi secara perlahan.

Dari hasil yang penulis dapatkan dari mustahik BAZNAS Kota Pasuruan bahwa dana ZIS yang disalurkan BAZNAS Kota Pasuruan sangat membantu mereka 
dalam pertumbuhan usaha mikro kecil menengah mustahik. Hal ini bisa dilihat dari omzet sebelum mendapatkan bantuan modal usaha dan sesudah mendapatkan bantuan modal usaha dana ZIS yang disalurkan oleh BAZNAS Kota Pasuruan. Mereka menyatakan bahwa dana ZIS yang disalurkan digunakan untuk tambahan modal usaha dan pengembangan usaha, dan yang lebih lagi adalah BAZNAS Kota Pasuruan dalam melakukan pengembalian modal ZIS tidak menggunakan system riba/bunga, sehingga membantu para mustahik terhindar dari rentenir yang mencekik dan menjauhkan mustahik dari perbuatan haram dan dosa. Sebelum adanya program bantuan modal ZIS, kebanyakan dari mustahik mendapatkan modal dari rentenir yang membebankan bunga/riba yang sangat tinggi berkisar 100\%-200\% yang tentunya sangat membebankan dan membebankan kepada para mustahik dalam pengembalian pinjaman, serta menimbulkan efek melanggar aturan agama yang melarang adanya bunga/riba. Oleh karena itu para mustahik sangat gembira dan antusias dengan adanya program modal usaha ZIS yang dijalankan oleh BAZNAS Kota Pasuruan, karena dapat membantu mereka terhindar dari himpitan rentenir dan dapat membantu perkembangan usaha mikro kecil menengah.

Dengan berkembangnya usaha mikro kecil menengah dengan modal berasal dari zakat, infaq, dan sedekah akan menyerap tenaga kerja. Hal ini mengakibatkan angka pengangguran bisa dikurangi, berkurangnya angka pengangguran akan berdampak pada meningkatnya daya beli masyarakat akan diikuti oleh pertumbuhan produksi, pertumbuhan sector produksi, pertumbuhan sector produksi inilah yang akan menjadi salah satu indikator adanya pertumbuhan ekonomi. Zakat, infaq, dan sedekah dapat dijadikan sebagai salah satu bentuk modal usaha bagi usaha mikro. Dengan demikian ZIS memiliki pengaruh yang sangat besar dalam berbagai hal kehidupan umat, diantaranya adalah pengaruh dalam bidang ekonomi. Pengaruh zakat, infaq dan sedekah lainnya adalah terjadinya pembagian pendapatan secara adil kepada masyarakat Islam.

Pada program Pasuruan Makmur ini para mustahik selain pendapatannya juga meningkat melalui usaha yang mereka jalankan juga dapat memenuhi kebutuhan hidupnya sehari-hari, dan dapat membiayai kebutuhan sekolah anak-anak mereka. Dan juga membantu pemerintah dalam hal pengentasan kemiskinan yang awalnya sebagai penerima zakat (mustahik) kemudian dapat berganti menjadi muzakki.

Modal usaha yang diberikan diharapkan terus berputar. Tidak hanya habis dalam beberapa hari saja, namun dapat digunakan untuk membantu usaha mereka yang dapat memenuhi kebutuhan hidupnya dan juga keluarga. Adanya zakat, infaq, dan sedekah ini sangat berpotensi, karena dapat dimanfaatkan dan didayagunakan sebaik-baiknya oleh para mustahik. Sehingga terbentuk kehidupan masyarakat yang harmonis, dengan tatanan social yang berlandaskan pada nilai-nilai keadilan dan kemanusiaan yang bersifat universal. Dengan begitu maka perekonomian mustahik akan sedikit terbantu dengan adanya dana bantuan modal usaha dari BAZNAS Kota Pasuruan. 


\section{E. Kesimpulan}

Berdasarkan pembahasan yang telah dikemukakan di dalam bab-bab sebelumnya mengenai Pengelolaan Zakat, Infaq dan Sedekah Dalam Upaya Meningkatkan Pendapatan Ekonomi Pelaku UMKM di BAZNAS Kota Pasuruan maka dapat ditarik kesimpulan sebagai berikut:

1. Dana zakat, infaq dan sedekah yang dikumpulkan oleh Badan Amil Zakat Nasional (BAZNAS) Kota Pasuruan bersumber dari warga masyarakat Kota Pasuruan dan Dinas-Dinas Kota Pasuruan. Pengelolaan dana ZIS ini disalurkan kepada para pelaku usaha mikro kecil menengah berupa barang atau uang untuk modal usahanya demi mengembangkan usaha mereka dan membantu meningkatkan ekonomi mereka.

2. Upaya meningkatkan pendapatan ekonomi pelaku UMKM melalui dan ZIS dari pengelolaan zakat, infaq, dan sedekah yang dilakukan oleh BAZNAS Kota Pasuruan dilihat dari perubahan tingkat ekonomi mustahik setelah mendapatkan dana bantuan modal usaha. Setelah mendapatkan bantuan modal usaha tersebut pendapatan atau perekonomian mustahik meningkat setiap bulannya, sehingga pengelolaan zakat, infaq dan sedekah yang dilakukan oleh BAZNAS Kota Pasuruan sudah sangat membantu dalam meringankan beban mustahik dan juga membebaskan mustahik dari jeritan rentenir. 


\section{DAFTAR PUSTAKA}

Anik, \& Prastiwi, I. E. (2019). Peran Zakat Dalam Meningkatkan Pertumbuhan Ekonomi Melalui Pemerataan "Equity." Proceeding Seminar Nasional \& Call For Papers, September, 119-138.

Antin Rakhmawati, Muhammad Nizar, \& Kholid Murtadlo. (2019). Pengaruh Electronic Word Of Mouth (E-WWOM) dan Viral Marketing Terhadap Minat Berkunjung dan Keputusan Berkunjung. Sketsa Bisnis, 6(1), 13-21.

Hendriyani, R., Chusna, K., Atmaja, B. T., M, I. I., \& Yanty, R. (2017). Metodologi Penelitian Ekonomi dan Bisnis. In Universitas Islam Negeri Sunan Kalijaga (Vol. 1, Issue Metodologi Penelitian).

Ilyas, R. (2018). Manajemen Permodalan Bank Syariah. Bisnis: Jurnal Bisnis Dan Manajemen Islam, 5(2), 323.

Indriantoro, N., \& Supomo, B. (2016). Metode Penelitian Bisnis untuk Akuntansi \& Manajemen. In Ekonomi.

Juwarta. (2015). Strategi Bisnis Guna Mengembangkan Kewirausahaan. Orbith, 11(1), 5359.

Khasanah, I., \& Suryaningsih, S. A. (2019). Pendistribusian Dana Zakat Sebagai Upaya Pemberdayaan Ekonomi Umat Pada Badan Amil Zakat Nasional (Baznas) Kota Pasuruan. Jurnal Ekonomi Islam, 2(3), 82-90.

Lukito. (2014). Filantropi Islam: Zakat dan Wakaf. Lukito Fatwa.

Muayyanah, S., Asmapane, S., \& ... (2019). Analisis Sumber Dan Penggunaan Kas Pada Badan Amil Zakat Nasional (BAZNAS) Kota Samarinda. Jurnal Ilmu Akuntansi ....

Nizar, M. (2015). Implementasi Pembiayaan Murabahah Dalam Meningkatkan Profitabilitas. An-Nisbah: Jurnal Ekonomi Syariah, 2(1).

Nizar, M. (2016). Proses Entrepreneurship, Kolaborasi Inovasi, Penciptaan Kekayaan Di Dalam Organisasi Bisnis (Studi Mikro Bank Syari'ah Universitas Yudharta Purwosari Pasuruan). Jurnal Hukum Islam, Ekonomi Dan Bisnis, 2(9), 91-103.

Purhantara, W. (2010). Metode Penelitian Kualitatif Untuk Bisnis. Graha Ilmu, 28(3), 307319.

Purnamasari, D., \& Firdaus, A. (2017). Analisis Strategi Penghimpunan Zakat Dengan Pendekatan Business Model Canvas. Human Fallah, 4(2), 1-27.

Rakhmawati, A., Rahardjo, K., \& Kusumawati, A. (2019). Faktor Anteseden dan Konsekuensi Green Supply Chain Management. Jurnal Sistem Informasi Bisnis, 9(1), 1. Sanihah, D. (2014). Pengelolaan Dana Zakat Produktif Untuk Pemberdayaan UMKM (Studi Kasus Rumah Zakat Kota Malang). Journal Malang.

Sekaran, U., \& Bougie. (2017). Metode Penelitian untuk Bisnis Pendekatan PengembanganKeahlian. In Metode Penelitian untuk Bisnis Pendekatan Pengembangan-Keahlian (pp. 53-79).

106 | Pengelolaan Zakat, Infaq dan Sedekah dalam Upaya Meningkatkan Pendapatan... 
Sisweda, A., Sahrani, S., \& Susanto, R. (2020). Nilai Pendidikan Islam Dalam Tradisi Sedekah Bumi (Studi Kasus di Dusun Melati Desa Olak-Olak Kubu Kecamatan Kubu Kabupaten Kubu Raya Tahun 2019). Journal of Research and Thought on Islamic Education (JRTIE), 3(1), 110-122.

Suryadi, N., \& Putri, Y. R. (2018). Analisis Penerapan Pembiayaan Qardhul Hasan Berdasarkan PSAK Syariah Pada BMT Al Ittihad Rumbai Pekanbaru. Jurnal Tabarru': Islamic Banking and Finance, 1(1), 37-50.

Syafi'i, M. (2019). Manajemen Pendistribusian Zakat Produktif Berdasarkan Akad Syar'i Dalam Mengembangkan Umkm Di Baznas Kabupaten Jember 2018-2019. At-Tasharruf “Jurnal Kajian Ekonomi Dan Bisnis Syariah," 1(1), 10-17.

Tatang Ruhiat. (2020). Strategi Pendayagunaan Strategi Pendayagunaan Zakat Produktif Untuk Pengentasan Kemiskinan (Implementasi Indeks Zakat di LAZISMU ). MALIA (TERAKREDITASI), 11(2), 277-288.

Wahiddudin, M. (2019). Pembiayaan Dan Usaha Mikro, Kecil Dan Menengah (UMKM) Terhadap Lembaga Keuangan Mikro Syariah (LKMS). AL-URBAN: Jurnal Ekonomi Syariah Dan Filantropi Islam, 3(1), 55-67.

Wicaksono, S. A. (2018). Analisis Faktor - Faktor Yang Mempengaruhi Pendapatan Umkm Pada Marketplace Online Tokopedia, Bukalapak, Dan Shopee. In Skripsi.

Yudhira, A. (2020). Analisis Efektivitas Penyaluran Dana Zakat, Infak dan sedekah Pada Yayasan Rumah zakat. Jurnal Ilmiah Akutansi Keuangan Dan Bisnis, 1(1), 1-15. 
..:: Malia: Jurnal Ekonomi Islam Vol. 12 No. 1, Desember 2020 ::..

108 | Pengelolaan Zakat, Infaq dan Sedekah dalam Upaya Meningkatkan Pendapatan... 